\title{
Synthesis, Characterization and Biological Activity Studies of Mixed Paracetamol- Ascorbic Acid Metal Complexes.
}

\author{
${ }^{* 1}$ BABAMALE, HF; LAWAL, A; RAJEE, OA; OLOYEDE, EA \\ ${ }^{l}$ Department of Industrial Chemistry, University of Ilorin, Ilorin, Nigeria \\ ${ }^{2}$ Department of Chemistry, University of Ilorin, Ilorin, Nigeria \\ *Correspondence Author: haliematshehu@gmail.com .+2348060059992 or amudat1112@gmail.com
}

\begin{abstract}
Mixed ligand-metal complexes of Paracetamol and Ascorbic acid were synthesized using $\mathrm{FeCl}_{2} \cdot 4 \mathrm{H}_{2} \mathrm{O}$, $\mathrm{CuCl}_{2} \cdot 2 \mathrm{H}_{2} \mathrm{O}, \mathrm{NiCl}_{2} \cdot 6 \mathrm{H}_{2} \mathrm{O}, \mathrm{CoCl}_{2} \cdot 6 \mathrm{H}_{2} \mathrm{O}$ and $\mathrm{ZnSO}_{4}$ salts based on two concentrations (3mmol and $5 \mathrm{mmol}$ ). The complexes were characterized using some physical techniques such as melting point, solubility, conductivity measurement and spectroscopic analyses such as UV-Visible spectroscopy, Atomic absorption spectroscopy, and Infrared spectroscopy. Based on the physical and spectroscopic results, the coordination of the metal was through the phenolic oxygen and carbonyl oxygen in paracetamol while it was through the carbonyl oxygen and C-2 hydroxyl group in ascorbic acid. The complexes were also screened for their antimicrobial activities against some isolates of Enterococcus faecalis, Staphylococcus aureus, Clostridium difficile, Klebsiella sp., Helicobacter pylori. @ JASEM
\end{abstract}

http://dx.doi.org/10.4314/jasem.v20i4.32

Keywords: Metal, Mixed ligand-metal complexes, Paracetamol, Ascorbic acid, Isolates.

Transition metal ions are playing an important role in biological processes in the human body, for example, Nickel (II), Copper (II) and Zinc (II) ions are the most abundant transition metals in humans. They are found either at the active sites or as structural components of a good number of enzymes. Metal complexes have been found to be particularly useful because of their potential to bind DNA via a multitude of interactions and to cleave the duplex by their intrinsic chemical, electrochemical and photochemical reactivity. Many biologically active compounds used as drugs possess modified pharmacological and toxicological potentials when administered in the form of metal based compounds. Various metal ions potentially and commonly used are cobalt, copper, nickel and zinc because of forming low molecular weight complexes and therefore, prove to be more beneficial against several diseases.

Paracetamol is classified as a mild analgesic. It is commonly used for the relief of headaches and other minor aches and pains and is a major ingredient in many cold and flu remedies. Paracetamol is not classified as non-steroidal anti-inflammatory drugs, and yet it is used to treat inflammatory pain, because it exhibits only weak anti-inflammatory property. Ascorbic acid is one form of Vitamin $\mathrm{C}$ and it can be synthesized industrially from glucose [5].It is a mild reducing agent and antioxidant and it typically reacts with oxidants of the reactive oxygen species, such as the hydroxyl radical which are capable of causing damage to animals and plants at the molecular level due to their possible interaction with nucleic acids, proteins, and lipids.

Therefore, it was deemed fit to have some other analgesic-antioxidant drug-metal complexes, due to their chemotherapeutic properties and hereby report the synthesis, characterization and biological activity studies of mixed paracetamol-ascorbic acid drug metal complexes.

\section{MATERIALS AND METHODS}

All the chemicals were reagent grade and used as commercially obtained (Aldrich, BDH) without further purification. Paracetamol was obtained from Newage pharmaceuticals, Abuja and ascorbic acid was also obtained from Emzor pharmaceuticals, Lagos.

The melting point of the ligands and the complexes was determined to ascertain their purity. The melting point was carried out using melting point Electrothermal IAg100 (Cat no.) M257450101 (Serial number) apparatus.

The conductivity test was carried out on the solution of the ligand and the complexes. The conductivity test was carried out at room temperature $\left(25^{\circ} \mathrm{C}\right)$ using HANNA instruments EC214 conductivity meter.

The IR spectral were recorded in solid state as $\mathrm{KBr}$ pellets using SHIMADZU infrared spectrophotometer from $4000 \mathrm{~cm}^{-1}$ to $500 \mathrm{~cm}^{-1}$

The UV-Vis analysis was recorded on a GENESYS 10S v1.200 2L7H311008.

The metal content of the complexes was determined by using $n$ Buck Scientific model 210VGP.

Evaluation of biological activity studies: The biological activity studies of the test compounds were assayed against isolates of Enterococcus faecalis, Staphylococcus aureus, Clostridium difficile, Klebsiella spp., Helicobacter pylori.

The biological activity was determined on the seeded nutrient agar on which $0.9 \mathrm{~cm}$ diameter wells punched. $100 \mathrm{ppm}$ of sterile solutions of the ligands 
and the complexes were made using methanol and DMSO as solvents, $0.2 \mathrm{~m} 1$ of the concentration was applied into the wells and incubated at $37^{\circ} \mathrm{C}$ for one to three days. The antibacterial activity was estimated on the basis of the size of inhibition zone formed around the well of the seeded agar plates.

Synthesis of Paracetamol-ascorbic acid drug metal complexes: The synthesis will be discussed based on two concentrations; $3 \mathrm{mmol}$ and $5 \mathrm{mmol}$.

For the 3mmol synthesis: The complexes were prepared by adding an aqueous solution of the metal chlorides and sulphates as the case may be to the aqueous solution of the ligands- dissolved in appropriate solvents and mixed together, (0.45gParacetamol and $0.53 \mathrm{~g}$ of ascorbic acid). The resulting mixture was then refluxed for 3 hours and left for some days to precipitate. The precipitate was then filtered, washed with appropriate solvents, airdried and then stored in sample bottles.
For the 5mmol synthesis: The complexes were prepared by adding an aqueous solution of the metal chlorides and sulphates, as the case may be, to the aqueous solution of the ligands- dissolved in appropriate solvents and mixed together, $(0.76 \mathrm{~g}$ Paracetamol and $0.81 \mathrm{~g}$ of ascorbic acid). The resulting mixture was then refluxed for 4 hours and left for some days to precipitate. The precipitate was then filtered, washed with appropriate solvents, airdried and then stored in sample bottles.

\section{RESULTS AND DISCUSSION}

The results of the analytical data, spectroscopic and biological studies are presented in Tables 1-3.

All the complexes were found to be stable. They have moderate to high melting point which differs from the ligands'. The conductivity measurement data for the metal complexes in appropriate solvents showed nonelectrolytic behavior in the solvents. Most of the complexes are not coloured and absorbed in the UV region.

Table 1: Analytical data and some physical properties of the complexes

\begin{tabular}{|c|c|c|c|}
\hline Compounds & M.P ( $\left.{ }^{0} \mathrm{C}\right)$ & M (\%) & Conductivity $(\mu S)$ \\
\hline Paracetamol & 176.5 & - & 19 \\
\hline Ascorbic acid & 204 & - & 64 \\
\hline \multicolumn{4}{|c|}{ Results for 3mmol synthesis } \\
\hline$[\mathrm{Co}(\mathrm{Par})(\mathrm{Asc})] \mathrm{Cl}_{2}$ & 173 & $16.31(16.03)$ & 11 \\
\hline$[\mathrm{Ni}(\mathrm{Par})(\mathrm{Asc})] \mathrm{Cl}_{2}$ & 181 & $15.31(15.00)$ & 13 \\
\hline$[\mathrm{Fe}(\mathrm{Par})(\mathrm{Asc})] \mathrm{Cl}_{2}$ & $>300$ & $15.26(15.32)$ & 13 \\
\hline$[\mathrm{Cu}(\mathrm{Par})(\mathrm{Asc})] \mathrm{Cl}_{2}$ & 193 & $14.63(14.00)$ & 23 \\
\hline$[\mathrm{Zn}(\mathrm{Par})(\mathrm{Asc})] \mathrm{SO}_{4}$ & 178 & $16.71(16.83)$ & 14 \\
\hline \multicolumn{4}{|c|}{ Results for $5 \mathrm{mmol}$ synthesis } \\
\hline$[\mathrm{Co}(\mathrm{Par})(\mathrm{Asc})] \mathrm{Cl}_{2}$ & $164-168$ & - & 12 \\
\hline$[\mathrm{Ni}(\mathrm{Par})(\mathrm{Asc})] \mathrm{Cl}_{2}$ & 230 & - & 14 \\
\hline$[\mathrm{Cu}(\mathrm{Par})(\mathrm{Asc})] \mathrm{Cl}_{2}$ & 254 & - & 19 \\
\hline$[\mathrm{Zn}(\mathrm{Par})(\mathrm{Asc})] \mathrm{SO}_{4}$ & 185 & - & 16 \\
\hline
\end{tabular}

Table 2: Selected IR spectral assignment of paracetamol-ascorbic acid metal complexes

\begin{tabular}{|c|c|c|c|c|c|c|c|}
\hline \multicolumn{8}{|c|}{ For $3 \mathrm{mmol}$ synthesis } \\
\hline Complexes / Ligands & $-\mathrm{C}-\mathrm{H}$ & $-\mathrm{C}=\mathrm{C}_{\mathrm{a}}$ & $-\mathrm{C}-\mathrm{N}$ & $-\mathrm{O}-\mathrm{H}$ & $-\mathrm{C}=\mathrm{O}$ & $-\mathrm{N}-\mathrm{H}$ & $\mathrm{C}-\mathrm{O}$ \\
\hline Paracetamol & 2792.9 & $\begin{array}{c}1444.68 \\
-566.20\end{array}$ & $\begin{array}{c}1107.14- \\
1257.89\end{array}$ & $1325.10(\mathrm{Phb})$ & 1664.57 & $\begin{array}{l}\text { 3327.21str. } \\
1566 \mathrm{~b}\end{array}$ & 1012.63 \\
\hline Ascorbic acid & - & - & - & $\begin{array}{c}3412.08- \\
3527.80 \text { str. }\end{array}$ & $\begin{array}{c}1664.517 \\
55.2\end{array}$ & - & $\begin{array}{l}1026.13- \\
1141.86\end{array}$ \\
\hline$[\mathrm{Ni}(\mathrm{Par})(\mathrm{Asc})] \mathrm{Cl}_{2}$ & 2794.8 & $\begin{array}{l}1440.83- \\
1564.27\end{array}$ & $\begin{array}{c}1109.07- \\
1255.66\end{array}$ & $\begin{array}{l}1371.39 \\
(\mathrm{Phb})\end{array}$ & 1656.85 & 3327.21 & 1014.56 \\
\hline$[\mathrm{Zn}(\mathrm{Par})(\mathrm{Asc})] \mathrm{SO}_{4}$ & - & $\begin{array}{l}1427.3- \\
1550.77\end{array}$ & $\begin{array}{l}\text { 1107.14- } \\
236.37\end{array}$ & 1325.10 & 1666.5 & 3332.7 & 1012.63 \\
\hline$[\mathrm{Co}(\mathrm{Par})(\mathrm{Asc})] \mathrm{Cl}_{2}$ & - & $\begin{array}{l}1440.83- \\
566.06\end{array}$ & $\begin{array}{l}1109.07- \\
321.24\end{array}$ & $1321.24(\mathrm{Phb})$ & 1654.9 & 3327.21 & 1016.49 \\
\hline$[\mathrm{Fe}(\mathrm{Par})(\mathrm{Asc})] \mathrm{Cl}_{2}$ & - & - & - & - & 1637.5 & 3336.85 & - \\
\hline$[\mathrm{Cu}(\mathrm{Par})(\mathrm{Asc})] \mathrm{Cl}_{2}$ & - & $\begin{array}{l}1148.5- \\
1570.06 \\
\end{array}$ & $\begin{array}{l}1107.14- \\
325.10 \\
\end{array}$ & $1325.10(\mathrm{Phb})$ & 1666.5 & 3334.92 & 1012.63 \\
\hline
\end{tabular}


For 5mmol synthesis

\begin{tabular}{|c|c|c|c|c|c|c|c|}
\hline Complexes & $-\mathrm{C}-\mathrm{H}$ & $-\mathrm{C}=\mathrm{C}_{\mathrm{a}}$ & $-\mathrm{C}-\mathrm{N}$ & $-\mathrm{OH}$ & $-\mathrm{C}=\mathrm{O}$ & $-\mathrm{N}-\mathrm{H}$ & $\mathrm{C}-\mathrm{O}$ \\
\hline$[\mathrm{Ni}(\mathrm{Par})(\mathrm{Asc})] \mathrm{Cl}_{2}$ & - & $\begin{array}{l}1449.25- \\
1556.55\end{array}$ & $\begin{array}{c}1109.07- \\
1255.66\end{array}$ & 1371.39(Phb) & - & 3327.21 & 1012.63 \\
\hline$[\mathrm{Zn}(\mathrm{Par})(\mathrm{Asc})] \mathrm{Cl}_{2}$ & 2794.85 & $\begin{array}{c}1440.83- \\
1566.2\end{array}$ & $\begin{array}{l}1109.07- \\
1255.66\end{array}$ & 1371.39(Phb) & 1656.85 & 3325.28 & 1014.56 \\
\hline$[\mathrm{Co}(\mathrm{Par})(\mathrm{Asc})] \mathrm{Cl}_{2}$ & - & - & 1109.07 & - & 1678.07 & - & 1012.63 \\
\hline$[\mathrm{Cu}(\mathrm{Par})(\mathrm{Asc})] \mathrm{Cl}_{2}$ & 2970.38 & 1448.54 & $\begin{array}{l}1111.0- \\
1317.38\end{array}$ & 1317.38(Phb) & - & - & 1060.85 \\
\hline
\end{tabular}

From the IR spectral results in Table 2, various absorption bands were seen on the spectra of the ligands and that of the complexes. Some of the bands present on the ligands disappeared from the complex while some of the bands shifted. This phenomenon indicates coordination of the metal to the ligand. For Paracetamol, an absorption was observed around $2792.93 \mathrm{~cm}^{-1}$ which is assigned to $-\mathrm{C}-\mathrm{H}$ stretch. The band is absent in ascorbic acid and the complexes except in Nickel complex of the $3 \mathrm{mmol}$ synthesis $\left(2794.85 \mathrm{~cm}^{-1}\right)$, Zinc and Copper complex of the 5 mmol synthesis with $2794.85 \mathrm{~cm}^{-1}$ and $2970.38 \mathrm{~cm}^{-1}$ respectively. Paracetamol has absorption at 1325.10 $\mathrm{cm}^{-1}$ which is responsible for phenol -O-H bending of the ligand. This band is absent in ascorbic acid but bands corresponding to $-\mathrm{O}-\mathrm{H}$ stretch were observed from $3412.08-3527.80 \mathrm{~cm}^{-1}$. The $-\mathrm{O}-\mathrm{H}$ stretch bands in ascorbic acid disappeared on other complexes due to coordination by protonation through the $-\mathrm{O}-\mathrm{H}$. And some complex showed a shift in phenol $-\mathrm{O}-\mathrm{H}$ band due to coordination while some did not. It can be inferred here that complexes that shows shift in the phenol bend band coordinated through the phenolic oxygen while those that didn't shift refused to coordinate through the phenolic oxygen.

An absorption was observed around $1664.57 \mathrm{~cm}^{-1}$ in Paracetamol and ascorbic acid which was assigned to $-\mathrm{C}=\mathrm{O}$. This disappearance and shift in the absorption bands was due to coordination through the carbonyl oxygen in both the paracetamol and ascorbic acid.

Furthermore, absorption was also observed around $3327.21 \mathrm{~cm}^{-1}$ in Paracetamol which is assigned to $-\mathrm{N}$ $\mathrm{H}$ stretch and also at $1566 \mathrm{~cm}^{-1}$ assigned to $-\mathrm{N}-\mathrm{H}$ bend. This band was not found on ascorbic acid but it was shifted in Zinc, Iron, Copper complexes of the 3 mmol synthesis and Zinc complex of the $5 \mathrm{mmol}$ synthesis while the band disappeared in cobalt and copper complexes of the $3 \mathrm{mmol}$ synthesis. All these is due to the coordination of the metal to the ligand by some complexes through this site. Cobalt and Nickel complexes of the $3 \mathrm{mmol}$ synthesis with Nickel complex of the $5 \mathrm{mmol}$ synthesis still retain the band as seen in Paracetamol showing that they do not coordinate through this site.

Another important band was observed around 3032.1 $\mathrm{cm}^{-1}$ in the ascorbic acid which was assigned to $=\mathrm{C}-\mathrm{H}$ stretch and also another band around $680-801.97$ assigned to $=\mathrm{C}-\mathrm{H}$ bend. This band disappeared or being shifted in the complexes but the bending vibration was present in most complexes. An absorption was also observed around 1107.14$1257.89 \mathrm{~cm}^{-1}$ which was assigned to $-\mathrm{C}-\mathrm{N}$ in Paracetamol. This band reflects throughout the whole complexes but was shifted in most of them. It can be inferred now that some metal coordinated through the phenolic oxygen and carbonyl oxygen in paracetamol and through the hydroxyl oxygen and carbonyl oxygen in ascorbic acid while some metal coordinated through the amine Nitrogen and carbonyl oxygen of the paracetamol.

By considering all the above analytical and spectroscopic data and in the absence of X-ray crystallographic data. The structures tentatively proposed for the complexes are show in Fig. 1 and Fig.2. 


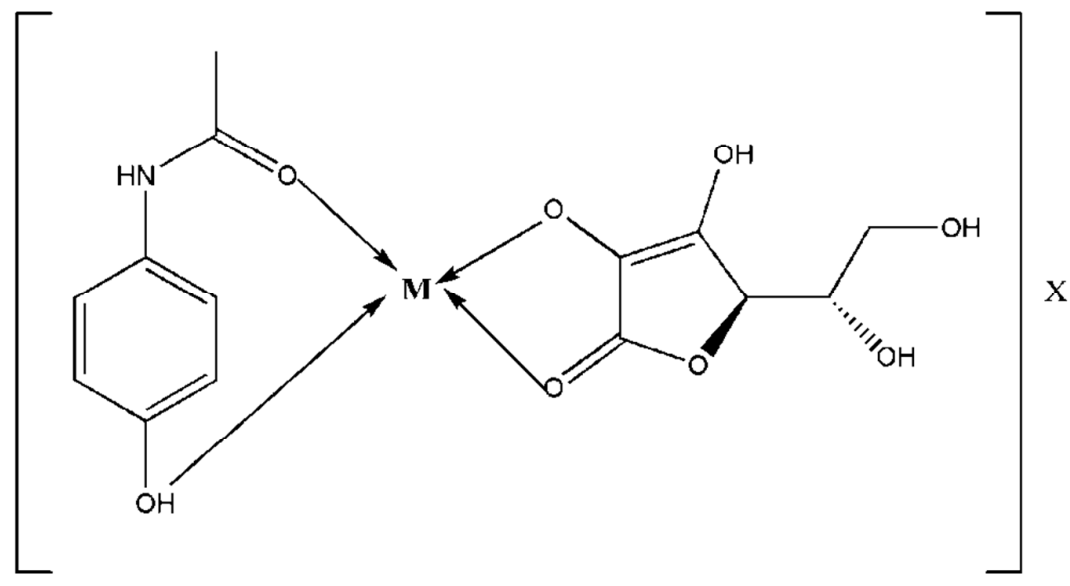

$\mathrm{M}=\mathrm{Ni}, \mathrm{Co}, \mathrm{Fe}$ (3mmol synthesis) and $\mathrm{X}=\mathrm{Cl}_{2}$ $\mathrm{M}=\mathrm{Ni}, \mathrm{Cu}, \mathrm{Co}\left(5 \mathrm{mmol}\right.$ synthesis) and $\mathrm{X}=\mathrm{Cl}_{2}$ $\mathrm{M}=\mathrm{Zn}$ (5mmol synthesis) and $\mathrm{X}=\mathrm{SO}_{4}$

Fig.1: Proposed structure of Paracetamol-ascorbic acid complex

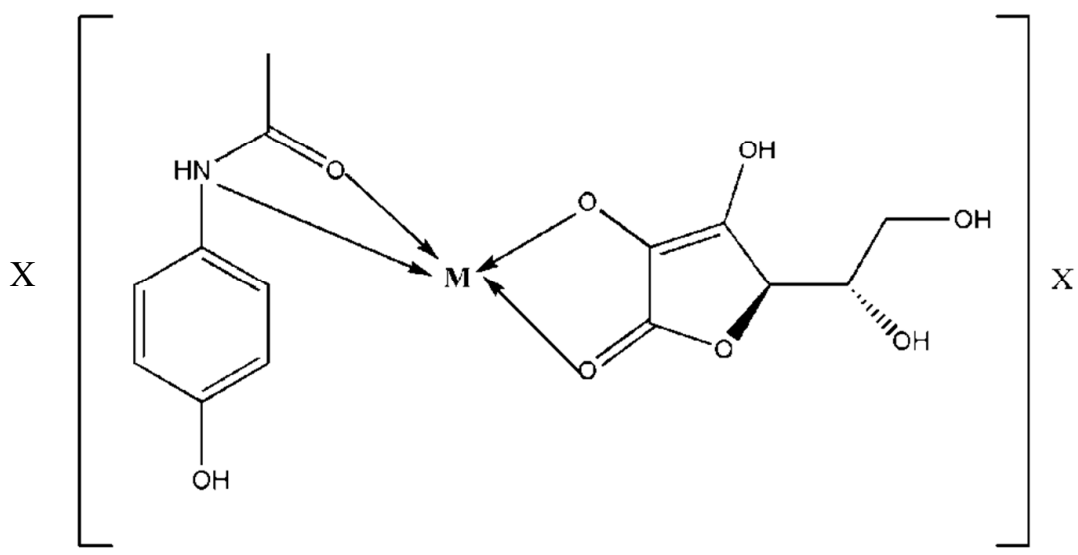

$\mathrm{M}=\mathrm{Cu}\left(3 \mathrm{mmol}\right.$ synthesis) and $\mathrm{X}=\mathrm{Cl}_{2}$

$\mathrm{M}=\mathrm{Zn}$ (3mmol synthesis) and $\mathrm{X}=\mathrm{SO}_{4}$

Fig.2: Proposed structure of Paracetamol-ascorbic acid complex 
Table 3: Result of biological activity studies

\section{For 3mmol synthesis}

\begin{tabular}{|c|c|c|c|c|c|c|c|c|c|c|c|c|c|c|c|}
\hline \multirow{3}{*}{$\begin{array}{l}\text { Complexes/ } \\
\text { Ligand }\end{array}$} & \multicolumn{15}{|c|}{ ZONE OF INHIBITION (mm) } \\
\hline & \multicolumn{3}{|c|}{ Enterococcus faecalis } & \multicolumn{3}{|c|}{$\begin{array}{c}\text { Staphylococcus } \\
\text { aureus }\end{array}$} & \multicolumn{3}{|c|}{ Clostridium difficile } & \multicolumn{3}{|c|}{ Klebsiella spp. } & \multicolumn{3}{|c|}{$\begin{array}{c}\text { Helicobacter } \\
\text { pylori }\end{array}$} \\
\hline & $24 \mathrm{~h}$ & $48 \mathrm{~h}$ & $72 \mathrm{~h}$ & $24 \mathrm{~h}$ & $48 \mathrm{~h}$ & $72 \mathrm{~h}$ & $24 \mathrm{~h}$ & $48 \mathrm{~h}$ & $72 \mathrm{~h}$ & $24 \mathrm{~h}$ & $48 \mathrm{~h}$ & $72 \mathrm{~h}$ & $24 \mathrm{~h}$ & $48 \mathrm{~h}$ & $72 \mathrm{~h}$ \\
\hline Paracetamol & 0 & 0 & 2 & 0 & 0 & 4 & 0 & 0 & 5 & 0 & 0 & 3 & 0 & 20 & 9 \\
\hline Ascorbic acid & 0 & 50 & 5 & 0 & 0 & 0 & 0 & 50 & 5 & 0 & 0 & 9 & 0 & 0 & 2 \\
\hline $\mathrm{Co}(\mathrm{Par})(\mathrm{Asc}) \mathrm{Cl}_{2}$ & 0 & 0 & 5 & 0 & 0 & 0 & 0 & 0 & 5 & 0 & 0 & 2 & 0 & 0 & 2 \\
\hline $\mathrm{Ni}(\mathrm{Par})(\mathrm{Asc}) \mathrm{Cl}_{2}$ & 0 & 10 & 14 & 0 & 0 & 9 & 0 & 0 & 0 & 0 & 10 & 10 & 0 & 0 & 0 \\
\hline $\mathrm{Cu}(\mathrm{Par})(\mathrm{Asc}) \mathrm{Cl}_{2}$ & 0 & 0 & 2 & 0 & 0 & 6 & 0 & 40 & 4 & 0 & 0 & 0 & 0 & 0 & 0 \\
\hline $\mathrm{Fe}(\mathrm{Par})(\mathrm{Asc}) \mathrm{Cl}_{2}$ & 0 & 0 & 1 & 0 & 0 & 0 & 0 & 0 & 3 & 0 & 0 & 0 & 0 & 0 & 0 \\
\hline $\mathrm{Zn}(\mathrm{Par})(\mathrm{Asc}) \mathrm{SO}_{4}$ & 0 & 0 & 7 & 0 & 0 & 0 & 0 & 10 & 0 & 0 & 0 & 0 & 0 & 10 & 0 \\
\hline
\end{tabular}

\section{For 5mmol synthesis}

\begin{tabular}{|c|c|c|c|c|c|c|c|c|c|c|c|c|c|c|c|}
\hline \multirow{3}{*}{ Complexes } & \multicolumn{15}{|c|}{ ZONE OF INHIBITION (mm) } \\
\hline & \multicolumn{3}{|c|}{$\begin{array}{c}\text { Enterococcus } \\
\text { faecalis }\end{array}$} & \multicolumn{3}{|c|}{$\begin{array}{c}\text { Staphylococcus } \\
\text { aureus }\end{array}$} & \multicolumn{3}{|c|}{ Clostridium difficile } & \multicolumn{3}{|c|}{ Klebsiella spp. } & \multicolumn{3}{|c|}{ Helicobacter pylori } \\
\hline & $24 \mathrm{~h}$ & 48h & 72h & $24 \mathrm{~h}$ & $48 \mathrm{~h}$ & 72h & 24h & $48 \mathrm{~h}$ & 72h & $24 h$ & 48h & $72 \mathrm{~h}$ & $24 \mathrm{~h}$ & $48 \mathrm{~h}$ & 72h \\
\hline $\mathrm{Co}(\mathrm{Par})(\mathrm{Asc}) \mathrm{Cl}_{2}$ & 0 & 0 & 6 & 0 & 0 & 0 & 0 & 20 & 6 & 0 & 0 & 6 & 31 & 0 & 0 \\
\hline $\mathrm{Ni}(\mathrm{Par})(\mathrm{Asc}) \mathrm{Cl}_{2}$ & 0 & 0 & 0 & 0 & 20 & 4 & 0 & 0 & 1 & 0 & 0 & 3 & 0 & 0 & 11 \\
\hline $\mathrm{Cu}(\mathrm{Par})(\mathrm{Asc}) \mathrm{Cl}_{2}$ & 0 & 5 & 31 & 35 & 25 & 32 & 0 & 0 & 15 & 0 & 3 & 0 & 0 & 0 & 0 \\
\hline $\mathrm{Zn}(\mathrm{Par})(\mathrm{Asc}) \mathrm{SO}_{4}$ & 0 & 0 & 0 & 0 & 0 & 0 & 12 & 35 & 0 & 0 & 0 & 0 & 0 & 10 & 0 \\
\hline
\end{tabular}

The complexes showed varied antimicrobial activity. During the study, it was observed that most of the complexes showed observable inhibition after 72 hours of inoculation. While some complexes showed inhibition after 24 hours, their inhibition reduced after 24 hours due to reduction in the concentration of the drugs. The Copper complex of the $5 \mathrm{mmol}$ synthesis showed the best inhibition against four out of five used microorganisms. Also, it was noticed that ascorbic acid showed the greatest decrease in zone of inhibition.

Conclusion: Reflux method has been used to synthesize a mixed paracetamol-ascorbic acid drug metal complexes where both the paracetamol and ascorbic acid act as bidentate ligands upon coordination. It was evident from this project work that increasing the concentration of a metal salt and also the hours of refluxing can have a great impact on complex formation. The synthesized complexes show satisfactory biological activities against some selected bacterial, so they are potential antimicrobial agents

\section{REFERENCES}

Maria K. R. B., Francis R. N. A., Vasanthi R. P and Paulraj A. (2013). Mixed Ligand Complexes Of Nickel(II), Copper(II) And Zinc(II) With Nicotinanilide And Thiocyanate. International Journal of Life science and Pharma research, 3(2), 1 .
Arounaguiri S., Easwaramoorthy D. and Ashokkumar A. (February 2000). Cobalt(III), nickel(II) and ruthenium(II) complexes of 1,10-phenanthroline family of ligands: DNA binding and photocleavage studies. Proc. Indian Acad. Sci. (Chem. Sci.) , 112(1), 1.

Marcela R. (n.d.). Metal Complexes as Antimicrobial Agents. A Search for Antibacterial Agents, 7388.

(SIGN), S. I. (2008). Guideline 106: Control of pain in adults with cancer. Scotland: National Health Service (NHS), (p. 6.1 and 7.1.1).

Lachapelle M.Y. and Drouin G. (2010). Inactivation dates of the human and guinea pig vitamin C genes. Genetica, 139(2), 199-207.

Caspi R. (2009). MetaCyc compound: monodehydroascorbate radical. MetaCyc. Retrieved from www.biocyc.org/META/NEW$\underline{\text { IMAGE} ? \text { type }=\text { COMPOUND\&object }=\text { CPD }-318}$

Lawal A. and Obaleye J.A. (June 2007). Synthesis, characterization and antibacterial activity of aspirin and paracetamol metal complexes. BIOKEMISTRI, 19(1), 9-15. 